\title{
Effect of Product Quality, Product Innovation, and Accuracy of Distribution Chains on Purchase Decisions that Impact on Improving Marketing Performance in the Zinc Steel Industry in Indonesia
}

\author{
Jasmani $^{1}$, Aidil Amin Effendy ${ }^{2}$, Aden Prawiro Sudarso ${ }^{3}$, Janudin $^{4}$, Denok Sunarsi ${ }^{5}$ \\ Mahnun Mas'adi ${ }^{6}$, Ahmad Nurhadi ${ }^{7}$ \\ Department of Management, Faculty of Economic, Universitas Pamulang, Banten, \\ Indonesia \\ dosen01770@unpam.ac.id'1, aidi100967@unpam.ac.id²,dosen01171@unpam.ac.id³, \\ dosen01789@unpam.ac.id ${ }^{4}$,denoksunarsi@unpam.ac.id ${ }^{5}$,dosen01017@unpam.ac.id ${ }^{6}$, \\ dosen01023@unpam.ac.id ${ }^{7}$

\begin{abstract}
The research objective is to see the effect of product quality, product innovation and the precision of distribution chain against purchasing decisions that impact on improving of marketing performance in the zinc steel industry in Indonesia. The results with path analysis show that the variable of the product quality, product innovation and the precision of distribution chain simultaneously affect the purchase decision of $49.5 \%$ significantly.
\end{abstract}

Keywords: Product Quality, Product Innovation, Distribution Chain Precision, Purchase Decision, Enhancement Of Marketing Performance.

\section{Introduction}

Indonesia is a country that has the attraction in many areas, some of which are in the field of business and the metal industry sector is needed in the manufacturing and other development sector. Currently Indonesia is attended to build infrastructure facility which can not deny from the rise of national steel needs. Steel is one of the most imported goods along 2019. Industrial competitiveness does not need to be offered, Indonesia should be able to take roles in this sector. export tax reduction from the Chinese government made the country's steel prices only $15-20 \%$ of local steel values.(Source: cnbnindonesia.com/new/2019). In improving the competitiveness of the industry, the government has actually issued several regulations such as the Regulation of trade minister no. 08 / M-DAG / PER / 2009 on the provisions of imported steel or iron which was then updated with Permendag No. 21 / M-DAG / PER / 6/2009 about changes in iron import and steel. Permendag No. 110 Year 2018 about provision of zinc Iron Import, Alloy Steel and its derivative products. The rule is intended to protect the national steel industry and encourage industrial doer in Indonesia. The doers of the zinc steel Industry are one of the parts of the doer of basic metal industry included in the upstream industry but also has a good integration to the downstream industry. 


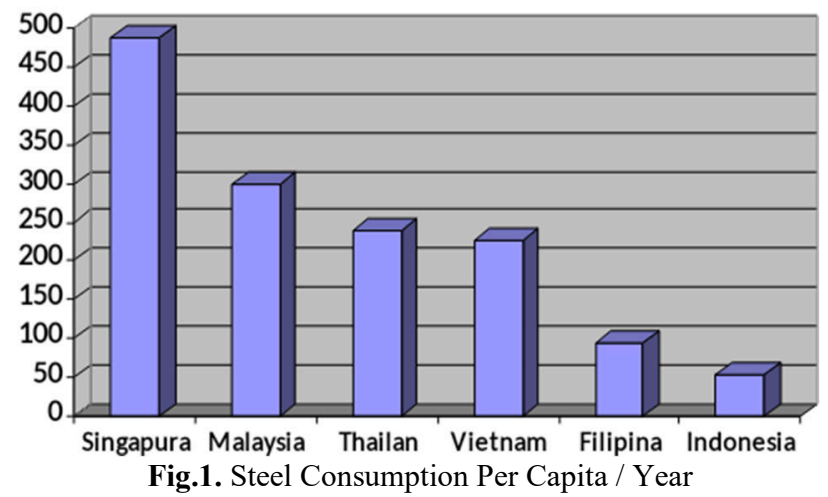

The graphic above shows that the current steel consumption per capita is still very low. The needs of steel consumption among the ASEAN countries,the consumption of Singapore countries $488 \mathrm{~kg}$ / year, Malaysia $299 \mathrm{~kg}$ / year, Thailand $239 \mathrm{~kg}$ / year, Vietnam $227 \mathrm{~kg}$ / year, Philippines 94 / kg / year, and Indonesia $52 \mathrm{~kg} /$ year,ranks 6 to among ASEAN countries. The consumption of per capita of this industry is calculated from the amount of rough steel production divided by the population of the country. The government itself has grouped the industry to several clusters, such as the first group of upstream steel with Blast Furnace technology from the Iron Seed process to become a Pig Iron and Direct Reduction Iron (IDR) the seed iron to bulk or pellet form. The second group is the steel industry such as slab, billet, holt rolled coil, the third is the downstream steel from the steel of finished flat product started by the largest consumer / project to the housing sector.

Product quality is one of the factors that influence purchasing decisions. A company must be able to maintain the quality of the product produced, because the quality of good products will increase consumer confidence. The better the quality of a product will further increase the interests of consumers in making the purchase of the product. By providing good product quality then the company can be superior to its competitors. Therefore the company should be able to understand the desire of consumers so as to create products with good quality according to consumer expectations and of course according to the standard of products required in terms of provisions. According to Kotler and Amstrong (2008: 272) explaining "the quality of the product is the characteristics of products or services that depend on its ability to satisfy the needs of consumer who are expressed or implied. All products certainly have established standards such as Indonesia Industrial Standards (SII), JIS G3141, ASTM British Std, Australian StD.

Another factor that influences the purchase decision is product innovation. In creating the product required innovation in order to blew the product with its competitors and what makes the product is superior to other similar products, can also provide consumer flexibility in choosing the product adjusting to the specifications and needs so that consumers do not move to buy other products or similar. The innovation itself is one of the determinants of the company's success to stay in even becoming more competitive.

Hubes (2012: 67) defines "innovation as a change or great idea in a set of related information between input and output". The opinion is also in harmony with Kotler and Amstrong (2008: 603: 604) which convey "with new product or with product repairs, information products and brands from developing companies through their own research and development efforts". Development of production has been much developed by industry perpetrators such as bail bandage, steel construction, wire combined with optical fiber, threaded, shawl, automotive 
frame component, pipe and gas path, corrosion resistant steel, rolling, ship construction, boiler, roof steel, florring, ducting and many others. All of these materials are already produced with more complete innovations and each has a good advantage.

Consumer purchasing decisions are an electoral process of several alternatives and solving the problem of consumers, and consumers can evaluate the various options to be able to determine the what they want to be taken next. The company needs to know well the purchase decision made by a consumer in order to more maximize the sale of its products, select the market, determine the target market and able to exist in targeted market so that the capacity of production is capable of doing sales with the maximum that ultimately able to increase expected profit. Kotler and Amstrong (2008: 179) explain that the purchase behavior passed by consumers.

Marketing performance is a benchmark in assessing the success of the creation of value that is a combination of strengthening innovation capabilities and in-depth understanding of market orientation. Various experts use different dimensions in measuring marketing performance. Sales growth can be seen from how much the increase in the sale of the same product is compared to a certain time unit. The sales level of the product will always be improved to achieve the specified target.

Market growth shows how contributed products are handled mastering the market of similar products compared with its competitor. Companies that have a broad portion of the market will dominate the sale of overall products compared with its competitor, so it can be seen how much the market is controlled than the main competitors. According to Tjiptono (2017: 239) marketing performance are based on profitability and productivity and Da Gama (2017:52) To be easier and to be understood.this research is limited in product quality,product innovation, The precision of distribution chain of its influence on purchasing decisions impact on improving of marketing performance in the zinc steel industry in Indonesia. The effect of product quality, product innovation and the precision of distribution chain against purchasing decisions impact on improving of marketing performance in the zinc steel industry in Indonesia.

\section{Library Overview}

\section{1 product quality}

Product quality is a dynamic condition associated with product, human or labor, process, and task, as well as an environment that meets or exceed consumer expectations. According to Kotler and Armstrong (2014: 349) explain that within satisfactory consumers, there are several product quality indicators: performance, durability, conformance, feature, aesthetics.

\section{2,2 Product Innovation}

Innovation is the process of creating new ideas and running in practice. Innovation is new ideas in the product, so the result is better. According to Hurley and Hult (1998) and Wahyono (2015: 25), filed two conceptions of innovation: (1) innovative thing, thought about openness for new ideas as a corporate culture aspect; (2) Capacity to innovate, the company's ability to use or apply the ideas, processes, or new products successfully.

\section{3 distribution Chain}


Distribution is a activity distributing of goods and services derived from producer to consumers. According to Assauri (2004) argues "the distribution is moving products from sources/manufacture to end consumers with distribution channels at the right time".

\section{4 satisfaction of buyer/consumer}

Purchase Decisions are one of the stages in the process of purchasing decision before postpurchase behavior. In entering the previous purchase decision stage, the consumer has been faced with several alternative options so that this stage of consumers will take action to decide to buy products based on the specified choice. According to Kotler (2017: 222) The purchase decision in this study is a series of processes through the consumer in deciding the purchase action

\subsection{Marketing peformance}

Marketing performance is a benchmark in assessing the success of the creation of value that is a combination from strengthening innovation capabilities and in-depth understanding of market orientation. Various experts use different dimensions in measuring marketing performance. According to Da Gama (2017: 52) as an important component that became the dimension of marketing performance

\subsection{Research hypothesis}

According to Sugiyono (2017) "hypothesis is a temporary answer to the problems, because of itself, then it is necessary to prove the truth through the empirical collected data".

\section{Method of Research}

The research sample was 96 respondents of Seng Ango Panel Industry in Indonesia, with saturated sample technique. This type of associative research is to determine or look for relationships between variables, The method of statistical analysis by testing the proposed hypothesis then draws conclusions

\section{Result of research}

\subsection{Descriptive Analysis}

Table 1. The result of statistics descriptive analysis Descriptive Statistics

\begin{tabular}{|c|c|c|c|c|c|}
\hline $\mathbf{N}$ & Desc & & & & i \\
\hline Product Quality (X1) & 96 & 29 & 46 & 37.44 & 3.710 \\
\hline Product Inovation (X2) & 96 & 31 & 46 & 38.09 & 3.372 \\
\hline Distribution Chain Accurancy (X3) & 96 & 30 & 46 & 37.99 & 3.848 \\
\hline Purchase Decision(Y) & 96 & 32 & 46 & 39.00 & 3.446 \\
\hline increasing of marketing performance (Z) & 96 & 32 & 45 & 39.70 & 3.229 \\
\hline Validity N (listwise) & 96 & & & & \\
\hline
\end{tabular}


Table 2. Testing result of multiple linier regression Coefficients $^{\mathrm{a}}$

\begin{tabular}{|c|c|c|c|c|c|c|}
\hline \multicolumn{4}{|c|}{ Model Unstandardized Coefficients } & Standardized & t & \multirow[t]{2}{*}{ Sig. } \\
\hline & B & & d. Err & Coefficients Beta & & \\
\hline \multirow[t]{4}{*}{1} & (Constant) & 6.846 & 3.418 & & 2.003 & .048 \\
\hline & product Quality (X1) & .224 & .078 & .242 & 2.888 & .005 \\
\hline & Product inovation $(\mathrm{X} 2)$ & .448 & .091 & .438 & 4.938 & .000 \\
\hline & $\begin{array}{l}\text { The precision of the } \\
\text { distribution chain }(X 3)\end{array}$ & .177 & .076 & .197 & 2.310 & .023 \\
\hline
\end{tabular}

\subsection{Purchase decision (Y)}

Based on the test results on above table, obtained regression equations $\mathrm{Y}=6,846+0.224 \times 1$ $+0.448 \times 2+0.177 \times 3$.

\subsection{Analysis of correlation coefficient}

The analysis of correlation coefficient based on table 3 .

Table 3. Testing Results of correlation coefficient of product quality to purchase decisions.

\begin{tabular}{llr|r}
\hline product quality(X1) & \multicolumn{1}{c}{ Correlations $^{\mathrm{b}}$} & \multicolumn{1}{c}{ purchase decision (Y) } \\
\hline Product quality(X1) & Pearson Correlation & 1 & $.501^{* *}$ \\
\cline { 2 - 4 } & Sig. (2-tailed) & & .000 \\
\hline purchase decision (Y) & Pearson Correlation & $.501^{* *}$ & 1 \\
\cline { 2 - 4 } & Sig. (2-tailed) & .000 & \\
\hline
\end{tabular}

**. Correlation is significant at the 0.01 level (2-tailed).

Table 4. Results of correlation coefficient testing of product innovation to purchase decisions. Correlations $^{\mathrm{b}}$

\begin{tabular}{cccc}
\hline \multicolumn{2}{c}{ Inovasi Produk (X2) } & Keputusan Pembelian (Y) \\
\hline product Innovation(X2) & Pearson Correlation & 1 & $.635^{* *}$ \\
& Sig. (2-tailed) & .000 \\
purchase decision(Y) & Pearson Correlation & .635 & 1 \\
& & $* *$ & \\
& Sig. (2-tailed) & .000 & \\
\hline
\end{tabular}

**. Correlation is significant at the 0.01 level(2-tailed).

Table 5. Results of correlation coefficient testing of distribution chain accuracy on purchase decision. Correlations $^{\mathrm{b}}$

\begin{tabular}{cccc}
\hline \multicolumn{2}{c}{ The precision of the distribution chain } & Purchase Decision (Y) \\
Distribusi (X3) & Sig. (2-tailed) & $.487^{* *}$ \\
\hline $\begin{array}{c}\text { The precision of the distribution } \\
\text { chain (X3) }\end{array}$ & Pearson Correlation & .000 \\
purchase decision (Y) & Pearson Correlation & $.487^{* *}$ & 1
\end{tabular}


Sig. (2-tailed) $\quad .000$

**. Correlation is significant at the 0.01 level(2-tailed).

\section{Listwise $\mathbf{N}=96$}

Table 6. Results of correlation coefficient test of product quality, product innovation and distribution chain precision simultaneously toward purchasing decisions

\begin{tabular}{lcccc}
\multicolumn{5}{c}{ Model Summary } \\
\hline \multicolumn{2}{l}{ Model R } & R Square & Adjusted R Square & d. Error of the Estimate \\
\hline 1 & $.704^{\mathrm{a}}$ & .495 & .479 & 2.488 \\
\hline
\end{tabular}

Predictors: (Constant), The precision of the distribution chain (X3), product quality(X1), product innovation (X2)

Table 7. Results of correlation coefficient test of purchasing decision toward increased marketing performance Correlations ${ }^{\mathrm{b}}$

\begin{tabular}{ccc|c}
\hline \multicolumn{2}{c}{ Purchase decision(Y) } & \multicolumn{2}{c}{ Improved marketing performance (Z) } \\
\hline Purchase decision (Y) & Pearson Correlation & 1 & $.691^{* *}$ \\
\cline { 2 - 3 } & Sig. (2-tailed) & .000 \\
\hline $\begin{array}{c}\text { Improved marketing } \\
\text { performance (Z) }\end{array}$ & Pearson Correlation & $.691^{* *}$ & 1 \\
\cline { 2 - 3 } & Sig. (2-tailed) & .000 & \\
\hline
\end{tabular}

**. Correlation is significant at the 0.01 level(2-tailed).

\subsection{Analysis of the determination coefficient}

Table 8. Results of determination coefficient test of product quality toward the Purchase Decision Model Summary

\begin{tabular}{lrrrr}
\hline $\begin{array}{l}\text { Model } \\
\text { R Square }\end{array}$ & Adjusted R Square & Error of the Estimate \\
\hline 1 & & & \\
\hline
\end{tabular}

\section{a) Product Quality (X1)}

Based on the test results obtained the determination value of 0.251 means that the product quality has an impact of $25.1 \%$ toward the purchase decision.

Table 9. The results of the determination coefficient test of product innovation toward purchasing decisi Model Summary

\begin{tabular}{cc|c|c|c}
\hline Model & R Square & Adjusted R Square & Std Error of the Estimate \\
$\mathbf{R}$ & & & \\
\hline 1 & $.635^{\mathrm{a}}$ & .403 & .397 & 2.676 \\
\hline
\end{tabular}

\section{b) Product inovation (X2)}


Table 10. Results of the determination coefficient testing of the distribution chain precision toward the purchase decision

Model Summary

\begin{tabular}{|c|c|c|c|}
\hline $\begin{array}{c}\text { Model } \\
\text { R } \\
\end{array}$ & R Square & Adjusted R Square & Std. Error of the Estimate \\
\hline $1.487^{a}$ & .238 & .229 & 3.025 \\
\hline
\end{tabular}

\section{c) Predictors: (Constant), The precision of the distribution chain (X3)}

Based on the test results obtained the determination value of 0.238 means that the accuracy of the distribution chain has an contribution impact of $23.8 \%$ toward the purchase decision.

Table 11. Results of the determination coefficient test of product quality, product innovation and distribution chain accuracy toward purchase decision

\begin{tabular}{l|c|c|c}
\multicolumn{3}{c}{ Model Summary } \\
\hline Model & R Square & Adjusted R Square & Std. Error of the Estimate \\
& & & \\
\hline $\mathbf{R}$ & & .479 & 2.488 \\
\hline 1 & $.704^{\mathrm{a}}$ & .495 & \\
\hline
\end{tabular}

d) Predictors: (Constant), The precision of the distribution chain, Producr quality, product inovation

Based on the test results obtained the determination value of 0.495 means that product quality, product innovation and the precision of the distribution chain simultaneously have influence contribution $49.5 \%$ toward the purchase decision.

Table 12. The test result of the determination coefficient of the purchase decisiontoward increasing marketing performance

\begin{tabular}{|c|c|c|c|}
\hline \multicolumn{4}{|c|}{ Model Summary } \\
\hline $\begin{array}{l}\text { Model } \\
\text { R }\end{array}$ & R Square & Adjusted R Square & Std. Error of the Estimate \\
\hline 1.691 & .477 & .472 & 2.347 \\
\hline
\end{tabular}

\section{e) Predictors: (Constant), purchase decision (Y)}

Based on the test results obtained the determination value of 0.477 means that the purchase decision has an influence contribution of $47.7 \%$ toward the purchase decision.

\subsection{Hypothesis Test}

\section{a) Test of partial hypothesis (test t)}

Table 13. The result of Product quality hypothesis test toward decision purchases

\begin{tabular}{ccc|c|c|c}
\multicolumn{7}{c}{ Coefficients $^{\mathrm{a}}$} \\
\hline $\begin{array}{c}\text { Model Unstandardized Coefficients } \\
\text { B }\end{array}$ & Std. Error & Standardized Coefficients Beta & t & Sig. \\
\hline 1 & (Constant) & 21.593 & 3.120 & 6.922 & .000 \\
\hline
\end{tabular}




\begin{tabular}{|ll|l|l|l|l|}
\hline Product quality (X1) & .465 & .083 & .501 & 5.607 & .000 \\
\hline
\end{tabular}

b) Buying decision (Y)

Table 14. The results of the hypothesis test of product innovation toward purchase decision. Coefficients $^{\mathrm{a}}$

\begin{tabular}{|c|c|c|c|c|c|c|}
\hline \multicolumn{4}{|c|}{ Model Unstandardized Coefficients } & \multirow{2}{*}{$\begin{array}{c}\text { Standardized } \\
\text { Coefficients Beta }\end{array}$} & \multirow[t]{2}{*}{$\mathbf{t}$} & \multirow[t]{2}{*}{ Sig. } \\
\hline & B & & Std. Error & & & \\
\hline \multirow[t]{2}{*}{1} & (Constant) & 14.278 & 3.114 & & 4.586 & .000 \\
\hline & Product innovation (X2) & .649 & .081 & .635 & 7.971 & .000 \\
\hline
\end{tabular}

\section{c) Purchase decision (Y)}

Table 15. Hypothesis test results of the distribution chain accuracy toward purchase decision

\begin{tabular}{ccc|c|c|c}
\hline \multicolumn{2}{c|}{$\begin{array}{c}\text { Model Unstandardized Coefficients } \\
\text { B }\end{array}$} & $\begin{array}{c}\text { Standardized } \\
\text { Coefficients } \\
\text { Beta }\end{array}$ & t & Sig. \\
\hline 1 & 22.422 & 3.079 & & 7.282 & .000 \\
\hline $\begin{array}{c}\text { (Constant) } \\
\text { The precision of the } \\
\text { distribution chain (X3) }\end{array}$ & .436 & .081 & .487 & 5.412 & .000 \\
\hline
\end{tabular}

\section{d) Purchase decision(Y)}

Table 16. The results of the hypothesis test of the purchase decision toward increased marketing performance. Coefficients $^{\mathrm{a}}$

\begin{tabular}{ccc|c|c|c|c}
\hline \multicolumn{2}{c}{$\begin{array}{c}\text { Model Unstandardized Coefficients } \\
\text { B }\end{array}$} & & Std. Error & $\begin{array}{c}\text { Standardized } \\
\text { Coefficients Beta }\end{array}$ & t & Sig. \\
\hline 1 & (Constant) & 14.459 & 2.736 & & 5.285 & .000 \\
\cline { 2 - 7 } & Purchase Decision (Y) & .647 & .070 & .691 & 9.261 & .000 \\
\hline
\end{tabular}

\section{e) Dependent Variable: Increased marketing decision (Z)}

Based on the test results on the above table, obtained the value of $(9,261>1.986)$, thus the proposed hypothesis, there is a significant effect between the distribution chain precision toward the accepted purchase decision.

\section{f) The Simultaneous Hypothesis Test (F test)}

hypothesis testing with the F test is used to determine which the simultaneous hypothesis is received. Hypothesis: There is a significant influence between product quality, product innovation and the distribution chain precision toward purchasing decisions.

Table 17. The test result of product quality hypothesis, product innovation and precision of distribution chain toward purchase decision.

\begin{tabular}{c|c|c|c|c}
\multicolumn{5}{c}{ ANOVA $^{\mathbf{a}}$} \\
\hline Model Sum of Squares & df & Mean Square & F & Sig. \\
\hline
\end{tabular}




\begin{tabular}{ccc|c|c|c|c}
\hline 1 & Regression & 558.518 & 3 & 186.173 & 30.076 & $.000^{\mathrm{b}}$ \\
\hline Residual & 569.482 & 92 & 6.190 & & \\
\hline Total & 1128.000 & 95 & & & \\
\hline
\end{tabular}

\section{Discussion of research results}

\section{a) The effect of product quality on the purchase decision}

Product quality has significant influence toward the purchase decision by correlation of 0.501 or has a strong relationship with an impact contribution of $25.1 \%(5,607>1.986)$. Thus the proposed hypothesis, there is a significant effect between product quality toward the accepted purchase decision.

\section{b) The effect of product innovation toward purchase decision}

Product innovations have a significant effect on the purchase decision by correlation of 0.635 or has a strong relationship with an impact contribution of of $40.3 \%(7,971>1.986)$. Thus the proposed hypothesis, there is a significant effect between product innovation to the accepted purchase decision.

\section{c) The effect of the distribution chain precision on the purchase decision}

Thus the proposed hypothesis,there is a significant effect between product innovation toward the accepted purchase decision. Effect of Product Quality, Product Innovation and Distribution Chain Precision on Purchase Decision Product quality, product innovation and distribution chain precision have a significant effect on purchasing decision obtained regression equations $\mathrm{Y}=6,846 \mathrm{~m}+0.224 \mathrm{x} 1+0.448 \times 2+0.177 \times 3$ product quality will guarantee performance.

\section{d) The influence of purchasing decisions on increased marketing performance}

Purchasing decisions have a significant effect on increased marketing performance with correlation of 0.691 or having a strong relationship with the effect contribution of $47.7 \%$. Hypothesis testing obtained the value of $t$ count $>T$ table or $(9,261>1.986)$. Thus the suggested hypothesis that there is a significant effect between the purchase decision on the increased marketing performance is accepted.

\section{Conclusions}

Some conclusions from the study

a) $\quad 25.1 \%$ contribution to the quality of the product has an effect on purchasing decisions based on the hypothesis test obtained by $(5.607>1.986)$.

b) Based on $(7,971>1,986) .40 .3 \%$ influence contribution that product innovation has an effect on purchasing decisions

c) $23.8 \%$ influence contribution to the accuracy of the distribution chain influencing purchasing decisions based on the hypothesis test $t$ count $>\mathrm{T}$ table or $(5,412>1,986)$.

d) Based on $(30.076>2,700)$. that product quality, product innovation and distribution chain 
accuracy have an effect on purchasing decisions.

e) Hypothesis test of $(9,261>1,986)$, so the purchasing decision has a significant effect on improving marketing performance of $47.7 \%$.

Research suggestions:

a) The doer of zinc steel industry should always keep the more quality products and have good resistance according to the specified standards.

b) the doer of zinc steel industry should always improve its creativity, finding new ideas and doing market surveys to find out what kind of products are currently favored by the market, with innovation of products that remain sustainable then the customer chances continue to buy will be great.

c) The doer of the zinc steel industry should shorten the distribution track is absolutely inefficient and ensuring the supply of goods is not hampered.

d) Company performance can be improved by empowering employees by training in quality of products and other capabilities so that the company has a reliable resources for optimizing the production capacity installed and able to achieve the company's desired profit.

\section{References}

[1] Algifari. (2015). “Analisis Regresi untuk Bisnis dan Ekonomi”. Yogyakarta: BPFE. Arikunto, Suharsimi (2014). "Prosedur Penelitian Suatu Pendekatan Praktek”. Jakarta: Rineka Cipta.

[2] D Sunarsi. (2014). Pengaruh Gaya Kepemimpinan, Motivasi dan Disiplin Kerja Terhadap Kinerja Pendidik. Universitas Pamulang

[3] Edisi Kelima. Semarang: Badan Penerbit Undip.

[4] Erlangga, H. (2020). The Challenges of Organizational Communication in the Digital Era. Solid State Technology, 63(4), 1240-1246.

[5] Erlangga, H., Sifatu, . W. O., Wibisono, . D., Siagian, . A. O., Salam, . R., Mas'adi, . M., Gunartin, ., Oktarini, . R., Manik, . C. D., Nani, ., Nurhadi, . A., Sunarsi, . D., Purwanto, . A. \& Kusjono, . G. (2020) Pharmaceutical Business Competition in Indonesia: A Review. Systematic Reviews in Pharmacy, 11 (10), 617-623. doi:10.31838/srp.2020.10.92

[6] Gumilar, I., Sunarsi, D. (2020). Comparison of financial performance in banking with high car and low car (Study of banks approved in the kompas 100 index for the period 2013-2017). International Journal of Psychosocial Rehabilitation. Volume 24 - Issue 7

[7] Gumilar, I., Sunarsi, D. (2020). Comparison of financial performance in banking with high car and low car (Study of banks approved in the kompas 100 index for the period 2013-2017). International Journal of Psychosocial Rehabilitation. Volume 24 - Issue 7

[8] Gunartin, Siagian, . A. O., Nufus, . K., Yusuf, . N., Supratikta, . H., Maddinsyah, . A., Muchtar, . A., Sari, . W. I., Sunarsi, . D., Akbar, . I. R., Arianto, . N., Purwanto, . A., Noryani, . \& Wijoyo, . H. (2020) A Systematic Literature Review of Education Financing Model in Indonesian School. Systematic Reviews in Pharmacy, 11 (10), 638-644. doi:10.31838/srp.2020.10.96

[9] Hidayat, D., Prabowo, B., \& Anwar, S. (2020). Organizational Leadership and Conflict in Human Resource Management Review. Solid State Technology, 63(6), 1372-1381.

[10] Hubeis, Musa dan Mukhamad Najib. 2014. Manajemen Strategik dalam Pengembangan Daya Saing Organisasi. Gramedia. Jakarta.

[11]Imam Ghozali (2017). "Aplikasi Analisis Multivariate Dengan Program SPSS”.

[12] Istijanto (2014) "Riset Sumber Daya Manusia”. Jakarta: PT. Gramedia Pustaka Jasmani, J. (2018). Pengaruh Kualitas Produk Dan Harga Terhadap Keputusan 
[13] Jasmani, J. (2019). Pengaruh Orientasi Pasar Dan Inovasi Produk Terhadap Keunggulan Bersaing Pada PT. Ragam Baja Nusantara. Disrupsi Binis, 2(1).

[14] Jasmani, J. (2019). Pengaruh Product Development Dan Promotion Mix Terhadap Peningkatan Penjualan Yang Berdampak Pada Keunggulan Bersaing. Jurnal Ekonomi Efektif, 1(2).

[15] Jasmani, J. (2019). Pengaruh Promosi Dan Pengembangan Produk Terhadap Peningkatan Hasil Penjualan. Jurnal Semarak, 1(3).

[16] Kembara, M.D, Hanny, R., Gantina, N., Kusumawati, I., Budimansyah, D., Sunarsi, D., Khoiri, A. (2020). Scientific Literacy Profile Of Student Teachers On Science For All Context. Solid State Technology. Vol. 63 No. 6

[17] Lukiastuti, Fitri, et.al (2020). The Influence of Entrepreneur's Personal Characteristics on SMES Performance Mediated by Entrepreneurial Orientation. International Journal of Psychosocial Rehabilitation. Volume 24 - Issue 8

[18] Maddinsyah, A., Sunarsi, D., Hermawati, R., Pranoto. (2020). Analysis of location selection effect on the user decision that influcence the success of the service business of micro, small and medium enterprise (MSME) in bandung timur region. International Journal of Advanced Science and Technology. Vol. 29 No. 06

[19] Maddinsyah, A., Sunarsi, D., Hermawati, R., Pranoto. (2020). Analysis of location selection effect on the user decision that influcence the success of the service business of micro, small and medium enterprise (MSME) in bandung timur region. International Journal of Advanced Science and Technology. Vol. 29 No. 06

[20] Mani, J. (2018). Pengaruh Peran Nilai Pelanggan Dan Citra Merek Terhadap Kinerja Pemasaran. Jurnal Mandiri, 2(2), 263-280.

[21] Nufus, K., Supratikta, H., Muchtar, A., Sunarsi, D. (2020). Analysis of Financial Performance: Case Study of PT. X Employee Cooperative. Utopía Y Praxis Latinoamericana. Año: 25, $\mathrm{N}^{\circ}$ Extra 10, 2020, pp. 429-444

[22] Pembelian Pada PT. Baja Mandiri Di Jakarta. Disrupsi Binis, 1(1).

[23] Peraturan menteri Perdagangan No. 08/M-DAG/PER/2009 Tentang ketentuan impor besi baja.

[24] Permendag No. 110 Tahun 2018 Tentang ketentuan import besi baja, baja paduan dan produk turunannya.

[25] Permendag No. 21/M-DAG/PER/6/2009 Tentang perubahan ketentuan impor besi atau baja.

[26] Purwanto, H., Fauzi, . M., Wijayanti, . R., Awwaly, . K. U. A., Jayanto, . I., Mahyuddin, ., Purwanto, . A., Fahlevi, . M., Adinugraha, H. H., Syamsudin, . R. A., Pratama, . A., Ariyanto, . N., Sunarsi, . D., Hartuti, . E. T. K. \& Jasmani, . (2020) Developing Model of Halal Food Purchase Intention among Indonesian Non-Muslim Consumers: An Explanatory Sequential Mixed Methods Research. Systematic Reviews in Pharmacy, 11 (10), 396-407. doi:10.31838/srp.2020.10.63

[27] Rao, Purba, (2012). "Measuring Consumer Perceptions Through Factor Analysis", The Asian.

[28] Rozi, A., \& Sunarsi, D. (2020). The Influence of Motivation and Work Experience on Employee Performance at PT. Yamaha Saka Motor in South Tangerang. Jurnal Office, 5(2), 65-74.

[29] Sobarna, A., Rizal, R. M., Hambali, S., \& Sunarsi, D. (2020). Influence Make a Match Model toward Communication skills in Physical and Health Pedagogical Concept. Solid State Technology, 63(6), 1355-1363.

[30] Sobarna, A., Sunarsi, D., \& Roinadi, D. K. (2020). The Effect of Pedagogic Competence Kids Athletic toward Motivation for Elementary School. Solid State Technology, 63(6), 1364-1371.

[31] Sugiyono (2017), "Metode Penelitian Administrasi : dilengkapi dengan Metode $R \& D$ ". Bandung: Alfabeta.

[32] Suhartanto (2014). “Metode Riset Pemasaran”. Bandung: Alfabeta

[33] Sunarsi, D. (2020). The Influence of Supply Chain Strategy on Employee Performance on Small and Medium Business in Beringharjo Market, Yogyakarta- Indonesia. International Journal of Supply Chain Management. Vol. 9, No. 5

[34] Sunarsi, D., Rohaeni, . N., Wulansari, . R., Andriani, . J., Muslimat, . A., Rialmi, . Z., Kustini, . 
E., Kristianti, . L. S., Rostikawati, . D., Effendy, . A. A., Purwanto, . A. \& Fahlevi, . M. (2020) Effect of e-Leadership Style, Organizational Commitment and Service Quality towards Indonesian School Performance. Systematic Reviews in Pharmacy, 11 (10), 472-481. doi:10.31838/srp.2020.10.71

[35] Supriyadi, D., Syafitri, . L. N. H., Widodo, S. F. A., Wahidi, R., Arinta, . Y. N., Nabhan, . F., Mufid, . A., Purwanto, . A., Fahlevi, . M., Sunarsi, . D. \& Cahyono, . Y. (2020) Innovation And Authentic Leadership Of Islamic University Lectures In Faculty Pharmacy Faculty: What Is The Role Of Psychological Capital?. Systematic Reviews in Pharmacy, 11 (8), 383-393. doi:10.31838/srp.2020.8.56

[36] Suryani, N. L., Sularmi, L., Eka, P. D., Sunarsi, D., \& Maddinsyah, A. (2020). The Analysis of Career Development and Placement of Employee Performance in Pt. Global Means of Transindo in Jakarta. Solid State Technology, 63(6), 1382-1389.

[37] Syobar, K., Hardiyan, A., Romlah, O. Y., Yusup, M., \& Sunarsi, D. (2020). The Effect of Service Quality and Price on Purchase Decisions in Woodpecker Coffee in South Jakarta. Solid State Technology, 63(6), 1491-1504.

[38] Tjiptono, Fandy. (2017). Strategi Pemasaran. Edisi Pertama. Yogyakarta: Andi Offset. 